\title{
Protein, prostaglandin and steroid synthesis in carun- cular and intercaruncular endometrium of sheep before implantation
}

\author{
J. K. Findlay*, Nicola Ackland, R. D. Burton, A. J. Davis, \\ Felicity M. Maule Walker, D. E. Walters and R. B. Heap \\ A.R.C. Institute of Animal Physiology, Babraham, Cambridge CB2 4AT, U.K.
}

\begin{abstract}
Summary. The effect of the presence of a preimplantation embryo on protein concentration, rate of protein synthesis, $\beta$-glucuronidase and acid phosphatase activities, steroid metabolism and prostaglandin $F$ production in caruncular and intercaruncular tissue have been studied for sheep at Day 15 of pregnancy. The rate of protein synthesis in both tissues was greater in pregnant than in non-pregnant animals, although the difference was only significant in caruncular endometrium. The effect in caruncular tissue was mimicked in ovariectomized animals treated with oestradiol. Localized changes in the caruncular tissue were observed in respect of PGF with an increased tissue concentration, an enhanced basal release when the tissue was incubated in the presence of indomethacin, and a decreased net production. Maximum production of PGF in the 2 tissues was unaffected by the presence of an embryo but it was enhanced by oestradiol or progesterone treatment in intercaruncular tissue of ovariectomized ewes. $\beta$-Glucuronidase and acid phosphatase activities and steroid metabolism were unaffected by pregnancy. However, in ovariectomized animals oestradiol treatment stimulated $\beta$-glucuronidase activity in endometrium and myometrium. Progesterone treatment stimulated acid phosphatase activity in the intercaruncular endometrium.

The results show that amongst several endometrial constituents investigated relatively few changes were detected by Day 15 post coitum, one day before definitive attachment. Those changes that did occur were associated with the dynamics of PGF production and the rate of protein synthesis, and were consistent with the production of a PGF binding component in caruncular endometrium which may be concerned with the protection of luteal function by redirection of uterine PGF production.

Canonical variate analysis revealed that changes on Day 15 of pregnancy were mimicked most closely in caruncular tissue by treatment of ovariectomized ewes with oestradiol and progesterone, and in intercaruncular tissue by oestradiol treatment only.
\end{abstract}

\section{Introduction}

The establishment of pregnancy in the ewe depends on maintenance of the function of the corpus luteum and continued progesterone secretion (Moor, 1968). This is achieved in the first instance by the conceptus which may suppress the luteolytic influence of the uterus by reducing secretion

* Present address: Medical Research Centre, Prince Henry's Hospital, St Kilda Road, Melbourne 3044, Australia. 
of prostaglandin (PG) F-2 $\alpha$ into the uterine vein (Thorburn, Cox, Currie, Restall \& Schneider, 1973; Barcikowski, Carlson, Wilson \& McCracken, 1974; Nett et al., 1976; Peterson, Tervit, Fairclough, Havik \& Smith, 1976). The mechanism by which the embryo achieves this or other antiluteolytic effects is uncertain (see Findlay, 1981), although it is known that the effect is initiated by Day 12 and that anti-luteolytic activity in embryo extracts resides in a soluble heat-labile, species-specific substance (Moor, 1968; Staples, Lawson \& Findlay, 1978), recently described as an acidic protein of molecular weight 70000 , and named trophoblastin (Martal, Lacroix, Loudes, Saunier \& Wintenberger-Torrès, 1979).

In addition to the endometrial changes associated with prolongation of luteal function, other preimplantation changes in the endometrium may result from the presence of an embryo. The first close contact between the trophoblast and uterine epithelium has been detected during the 15 th day of gestation but no morphological changes within the epithelium have been described before definitive attachment on Day 16 (Boshier, 1969). However, there are changes in protein secretion by the uterus during the normal cycle and early pregnancy as indicated by studies of proteins in uterine flushings (Menezo, 1973; Roberts, Parker \& Symonds, 1976) and enzyme activities in uterine tissues (Murdoch, 1970a, b; Murdoch \& O'Shea, 1978; O'Shea \& Murdoch, 1978; Zamiri \& Blackshaw, 1979). Moreover, lysosomes and heterophagosomes with acid phosphatase and $\beta$-glucuronidase activities play an important role in the process of implantation and the remodelling of tissue in certain species (Woessner, 1969). However, these changes have not been studied in relation to PG production in different tissues within the uterus, although it is well known that PGF- $\alpha$ production (Scaramuzzi, Baird, Boyle, Land \& Wheeler, 1977; Louis, Parry, Robinson, Thorburn \& Challis, 1977; Baird, 1978) and protein synthesis (Miller \& Moore, 1976) are both influenced by ovarian steroid hormones.

The purpose of this study was to determine whether the presence of a preimplantation embryo affected endometrial protein synthesis, PGF- $2 \alpha$ production and steroid metabolism in localized regions of the endometrium, and whether these effects could be mimicked in ovariectomized ewes treated with steroid hormones.

\section{Materials and Methods}

\section{Animals and treatments}

Clun Forest ewes from the Institute's flock were used intact $(\mathrm{N}=9)$ or ovariectomized $(\mathrm{N}=$ 16). Ovariectomy was performed at least 3 weeks before the start of the experiment which was carried out between July and October. Animals were allocated to 6 groups of similar mean liveweight (Table 1) as follows; Group 1, 5 intact, non-pregnant ewes; Group 2, 4 intact, pregnant ewes; Group 3, 4 ovariectomized, control ewes; Group 4, 4 ovariectomized ewes treated with oestradiol-17ß; Group 5, 4 ovariectomized ewes treated with progesterone; and Group 6, 4 ovariectomized ewes treated with oestradiol-17 $\beta$ and progesterone.

Intact ewes had progesterone implants (Sil-Estrus: Abbott Laboratories, Sydney) placed s.c. in the inguinal region for 12 days to synchronize oestrus. After removing the implants, the ewes were kept with vasectomized rams to detect oestrus and then placed with a vasectomized ram (Group 1) or a fertile ram (Group 2). The day of mating was designated Day 0 and the ewes were killed on Day 15.

Hormone treatments were selected to minic the ovarian secretion rates of oestradiol-17 $\beta$ and progesterone during the normal cycle (Legan, Karsch \& Foster, 1977). Oestradiol-17 $\beta$ (Ikapharm, Israel) was administered by means of Silastic implants (Dow Corning, Michigan: $100 \mathrm{mg}$ steroid, range 95-105 mg). The day on which the oestradiol implants were inserted was designated Day 0 of treatment. On Day 3 a progesterone implant (Sil-Estrus: Abbott) was placed s.c. in the inguinal region in animals of Groups 5 and 6 , contralateral to the oestrogen implant if present. Implants were inserted under local anaesthesia ( $2 \%$ lignocaine hydrochloride: Astra, Watford) and were recovered when the ewes were killed on Day 15. 
Blood samples were taken from all ewes immediately before autopsy and plasma was stored at $-15^{\circ} \mathrm{C}$. At autopsy, ewes were anaesthetized with pentobarbitone sodium (Sagatal: May \& Baker, Dagenham) and then exsanguinated. The reproductive tract and tissue samples of liver, kidney, lung and skeletal muscle were collected and stored on ice in sterile containers. The ovaries, cervix and connective tissues were trimmed from the uterus which was weighed and then flushed with $10 \mathrm{ml} 0.154 \mathrm{M}-\mathrm{NaCl}$ (saline). The uterine flushings of intact ewes were examined for the presence of a viable blastocyst. The myometrium was dissected from the uterus. The larger blood vessels and connective tissue were separated from the endometrium and discarded. The endometrium was then opened and individual caruncles were removed from the intercaruncular endometrium. All tissues were chopped finely with scissors and stored on ice until used.

\section{Protein synthesis}

Leucine incorporation in vitro. The rate of protein synthesis in caruncular, intercaruncular, myometrial and skeletal muscle tissues was estimated by the incorporation of ${ }^{3} \mathrm{H}-$ and ${ }^{14} \mathrm{C}$-labelled leucine into protein by using a method developed by Wyatt (1978). Approximately $50 \mathrm{mg}$ tissue (in quadruplicate) were placed in $1 \mathrm{ml}$ tissue culture medium (M 199: Gibco Bio-Cult Ltd, Paisley) which contained saturating concentrations of leucine and was supplemented with $220 \mathrm{kBq} \mathrm{L}-\left[4-5{ }^{3} \mathrm{H}\right]$ leucine (sp.act. $1.85 \mathrm{TBq} / \mathrm{mmol}$ : Radiochemical Centre, Amersham) or $70 \mathrm{kBq} \mathrm{L}-\left[\mathrm{U}^{14} \mathrm{C}\right]$ leucine (sp.act. $13 \mathrm{GBq} / \mathrm{mmol}$ : Radiochemical Centre). Tissue was incubated for $4 \mathrm{~h}$ at $37^{\circ} \mathrm{C}$ in an humidified atmosphere of $5 \% \mathrm{CO}_{2}$ in oxygen. After incubation, the medium (which contained $<1 \%$ of total labelled protein) was discarded and the tissue transferred to small glass tubes and washed 3 times with cold M199. Lysis buffer ( $1 \mathrm{ml}$ 8 M-urea, $1 \% \mathrm{v} / \mathrm{v}$ sodium dodecyl sulphate (SDS: $\mathrm{BDH}$ Chemicals, Poole) and $5 \% \mathrm{v} / \mathrm{v}$ mercaptoethanol $(\mathrm{BDH})$ ) was added and tissue protein was extracted by freezing on solid $\mathrm{CO}_{2}$ and thawing with vortex mixing 3 times. After centrifugation at $600 \mathrm{~g}$ for $15 \mathrm{~min}, 200 \mu \mathrm{l}$ supernatant were mixed at $4^{\circ} \mathrm{C}$ with $300 \mu \mathrm{l} 0.01 \mathrm{M}$-phosphate-buffered saline containing $0 \cdot 154$ $\mathrm{M}-\mathrm{NaCl}, 1 \%(\mathrm{w} / \mathrm{v})$ bovine serum albumin (Armour Pharmaceuticals Company Ltd, Eastbourne), $0 \cdot 1 \%(\mathrm{w} / \mathrm{v})$ L-leucine $(\mathrm{BDH})$, and $500 \mu 10 \%(\mathrm{w} / \mathrm{v})$ trichloroacetic acid (TCA). The tubes were mixed by vortexing, centrifuged $\left(600 \mathrm{~g}\right.$ for $3 \mathrm{~min}$ at $4^{\circ} \mathrm{C}$ ) and the supernatant discarded. The precipitate was washed 3 times with ice-cold $5 \%(w / v)$ TCA and then dissolved in $0.5 \mathrm{ml}$ Soluene (Packard Instrument Company Inc., Illinois) overnight at room temperature. Scintillation fluid ( $5 \mathrm{ml}, 0.4 \%$ 2,5-diphenyloxazole in toluene) was added and the contents were transferred to vials for counting in a Packard Tri-Carb liquid scintillation spectrometer. Corrections were made for efficiency of counting $\left({ }^{3} \mathrm{H}, 40 \% ;{ }^{14} \mathrm{C}, 70 \%\right)$ and the radioactivity calculated and expressed as $\mathrm{nmol} / \mathrm{mg}$ tissue protein or $\mathrm{nmol} / \mathrm{mg}$ wet tissue. The latter data are not presented since the effects were similar to those expressed as $\mathrm{nmol} / \mathrm{mg}$ protein.

The method used to estimate the protein concentration of maternal and embryonic tissues was based on that of Gottesman (1978) so that the incorporation of radioactivity and protein content were measured in the same tissue extract. Tissue extract in lysis buffer (without mercaptoethanol) was added to $500 \mu \mathrm{l}$ cold TCA $(20 \% \mathrm{w} / \mathrm{v}$, containing $0 \cdot 1 \% \mathrm{w} / \mathrm{v} \mathrm{L-leucine})$. After standing for $30 \mathrm{~min}$ at $4^{\circ} \mathrm{C}$, the tubes were centrifuged at $600 \mathrm{~g}$ for $30 \mathrm{~min}$, the supernatant was discarded and the precipitate was washed 3 times with ice-cold $10 \%$ TCA, once with $1 \mathrm{ml}$ cold diethyl ether and then dried. The precipitate was dissolved in $100 \mu \mathrm{l} 0 \cdot 15 \mathrm{M}$-Tris- $\mathrm{HCl}$ buffer, pH $6 \cdot 5$, containing $8 \mathrm{M}$-urea and $1 \%(\mathrm{w} / \mathrm{v})$ SDS. Aliquots were taken for counting radioactivity, for measuring protein content (Lowry, Rosebrough, Farr \& Randall, 1951), and for polyacrylamide gel electrophoresis (PAGE) (Davis, 1964). The protein content of tissues from Groups 3-6 was measured in lysis buffer (without mercaptoethanol) on extracts of $50 \mathrm{mg}$ tissue by the Folin-Lowry method but incorporation of labelled leucine was determined in 
another aliquot of tissue. There was no significant difference between protein concentrations measured by both methods.

Electrophoresis. Selected samples ( $500 \mu \mathrm{g}$ protein) were treated for $2 \mathrm{~min}$ at $100^{\circ} \mathrm{C}$ with $50 \mu \mathrm{l}$ Tris-urea-SDS buffer after adding $1 \%(\mathrm{v} / \mathrm{v})$ mercaptoethanol. They were subjected alone, or together with a sample, labelled with the other isotope, from another animal (e.g. pregnant and non-pregnant), to PAGE in $10 \%$ acrylamide (BDH), $0.1 \%$ SDS gels (high mol. wt range, $25000-150000$ ), or $10 \%$ acrylamide, $0.1 \%$ SDS gels containing 8 M-urea and acrylamide: $N^{\prime} N^{\prime}$-methylene-bisacrylamide (BDH), 2:1 (low mol. wt range, 10 000-75 000). The gels were calibrated with respect to molecular weight ranges using the mobility of standards (BDH, mol. wt markers for SDS-PAGE 53 000-265000 and 14 300-71 500) relative to bromophenol blue $\left(R_{\mathrm{F}}=1\right)$. Gels were run for $4-5 \mathrm{~h}$ at $3 \mathrm{~mA} / \mathrm{gel}$, frozen and cut into 1 or $2 \mathrm{~mm}$ slices. Each slice was incubated overnight at $37^{\circ} \mathrm{C}$ with $250-300 \mu$ Soluene; $5 \mathrm{ml}$ scintillation fluid were added and the ${ }^{14} \mathrm{C}$ and ${ }^{3} \mathrm{H}$ activity counted at appropriate settings on a Packard liquid scintillation counter with external standard ratios to adjust for quenching. The ${ }^{3} \mathrm{H} /{ }^{14} \mathrm{C}$ ratio in each gel slice and pmol leucine incorporated $/ \mathrm{mg}$ protein were calculated.

\section{$\beta$-Glucuronidase and acid phosphatase}

The activities of $\beta$-glucuronidase and acid phosphatase were measured in the tissue homogenates by a modified $p$-nitrophenol method (Fishman, 1974). Tissue (200-250 mg) was finely chopped and then homogenized in 3-4 $\mathrm{ml} \mathrm{0.1} \mathrm{M-acetate} \mathrm{buffer} \mathrm{(pH} \mathrm{4)} \mathrm{for} \mathrm{10-15} \mathrm{sec} \mathrm{with}$ a Polytron homogenizer. The homogenate was made up to $10 \mathrm{ml}$ with $0.1 \mathrm{M}$-acetate buffer and kept at $0-4{ }^{\circ} \mathrm{C}$. All samples were analysed in duplicate at optimal substrate and enzyme concentrations. The activities of the enzymes in liver and kidney were used as positive controls and did not differ between treatments. For acid phosphatase, each tube contained $1 \mathrm{ml} 5.5$ mM-p-nitrophenyl phosphate (Boehringer Mannheim, Lewes; or Sigma London, Poole, - in 50 $\mathrm{mm}$ citrate buffer, $\mathrm{pH} 4.8$, and $0.1 \mathrm{ml}$ homogenate (approximately $230 \mu \mathrm{g}$ protein). After incubating for $30 \mathrm{~min}$ at $37^{\circ} \mathrm{C}, 10 \mathrm{ml} 0.02 \mathrm{M}-\mathrm{NaOH}$ were added and the absorbance read at 405 $\mathrm{nm}$ against a blank (homogenate added after $\mathrm{NaOH}$ ). For $\beta$-glucuronidase, each tube contained $0.2 \mathrm{ml} 1.5 \mathrm{mM}-p$-nitrophenyl glucuronide (Sigma) in distilled water, $0.3 \mathrm{~mm}$-acetate buffèr, 0.4 $\mathrm{ml}$ distilled water and $0.1 \mathrm{ml}$ homogenate. After mixing, the tubes were stoppered and incubated for $2 \mathrm{~h}$ at $37^{\circ} \mathrm{C}$ and then $4 \mathrm{ml}$ Dupanol-glycine $(0.22 \mathrm{M})$ were added. The absorbance was read 10 min later at $405 \mathrm{~nm}$ against a blank (homogenate added after Dupanol-glycine).

The protein content of tissue homogenates was measured by the method of Lowry et al. (1951). The activity of the enzymes was expressed as mmol formed in $30 \mathrm{~min}$ (acid phosphatase) or $2 \mathrm{~h}$ ( $\beta$-glucuronidase), by converting the absorbance at $405 \mathrm{~nm}$ to $\mathrm{mmol} p$-nitrophenol from a calibration line over the range 3.32 to $62.5 \mathrm{mmol} /$ tube $(y=60.4 x-0.83$, where $y=\mathrm{mmol}$ $p$-nitrophenol, and $x=$ absorbance at $405 \mathrm{~nm}$ ). The theoretical limit of detection was $0.8 \mathrm{mmol}$ or $0.35 \mathrm{mmol} / \mathrm{mg}$ protein at $0.23 \mathrm{mg}$ protein $/$ tube. The results were expressed as $\mathrm{mmol} / \mathrm{mg}$ protein or $\mathrm{mmol} / \mathrm{mg}$ wet weight (data not shown).

\section{Steroid metabolism}

The metabolism of androstenedione, oestrone and oestrone sulphate was measured in minces of the uterine tissues. Tissue ( $300 \mathrm{mg}$ ) was finely chopped with scissors and incubated in duplicate in $\mathrm{M} 199$ containing $37 \mathrm{kBq}$ steroid substrate for $3 \mathrm{~h}$ in $5 \% \mathrm{CO}_{2}$ in oxygen. Labelled steroids, checked for purity before incubation, were obtained from the Radiochemical Centre, Amersham: $\left[1,2,6,7-{ }^{3} \mathrm{H}\right]$ androstenedione, sp.act. $3 \cdot 21 \mathrm{TBq} / \mathrm{mmol} ;\left[6,7-{ }^{3} \mathrm{H}\right]$ oestrone, sp.act. $1 \cdot 7$ $\mathrm{TBq} / \mathrm{mmol}$; and $\left[6,9-{ }^{3} \mathrm{H}\right]$ oestrone sulphate, potassium salt, sp.act. $1.44 \mathrm{TBq} / \mathrm{mmol}$. After 
incubation, media (with tissue) were extracted and ether-soluble, phenolic and aqueous-soluble steroids were isolated and chromatographed by the methods described by Gadsby, Heap \& Burton (1980).

\section{Prostaglandin $F(P G F)$}

Sample collection was completed within 30 min of slaughter and duplicate determinations of the following items were made on chilled, diced samples (10-50 mg blotted weight) of tissues.

Initial concentration. The tissue was rapidly brought to $\mathrm{pH} 4.0$ with citric acid $(3.4 \mathrm{~mol} / \mathrm{l})$ to inhibit PG synthesis and metabolism and then homogenized in $5 \mathrm{ml}$ methanol at $4^{\circ} \mathrm{C}$. The methanol layer was removed and the extraction repeated with $2 \mathrm{ml}$ methanol. Extracts were combined and after being taken to dryness in a vacuum oven at $45^{\circ} \mathrm{C}$ the residue was dissolved in $1.0 \mathrm{ml}$ Tyrode's solution containing $(\mathrm{mmol} / \mathrm{l}) \mathrm{NaCl}, 1.37 ; \mathrm{KCl}, 2.7 ; \mathrm{CaCl}_{2}, 1.8 ; \mathrm{MgCl}_{2}$, $1.05 ; \mathrm{NaH}_{2} \mathrm{PO}_{4}, 0.42 ; \mathrm{NaHCO}_{3}, 12 ;$ glucose, $5 \cdot 6$, and stored at $-20^{\circ} \mathrm{C}$.

Basal release. Tissue was rapidly washed in about $100 \mathrm{ml}$ cold Tyrode's solution to remove debris and readily-released prostaglandins. The tissue was then finely chopped in a further $5 \mathrm{ml}$ cold Tyrode's solution containing $4 \mu \mathrm{g}$ indomethacin $/ \mathrm{ml}(20 \mu \mathrm{l}, 1 \mathrm{mg} / \mathrm{ml}$ in $96 \%$ ethanol) and incubated in $5 \mathrm{ml}$ of the same solution. Incubations were carried out in $5 \% \mathrm{CO}_{2}$ in oxygen at $37^{\circ} \mathrm{C}$ for $90 \mathrm{~min}$ with constant shaking. After completion of incubation $20 \mu \mathrm{l}$ ethanol were added to each sample. Aliquots of the incubation medium were removed and stored at $-20^{\circ} \mathrm{C}$ before assay. In the presence of $4 \mu \mathrm{g}$ indomethacin/ml the appearance of PGF- $\alpha$ in the medium was reduced by $98 \%$. The amount in the medium under these conditions was assumed to be previously sequestered PGF and termed basal release.

Residual concentration. PGF in tissue after incubation for basal release was extracted using the same method as for initial concentration.

Net production. The method for this determination was as for basal release except that indomethacin was added at the end of the incubation. Time course studies showed that the amount of PGF measured in the incubation medium reached a maximum within $1 \mathrm{~h}$ and it was assumed that this value represented the sum of basal release and de-novo synthesis of PGF. Net production was calculated as the amount of PGF formed during incubation corrected for basal release.

Maximum production. The method for this determination was as for basal release except that indomethacin was replaced during incubation by $20 \mu \mathrm{g}$ arachidonic acid $/ \mathrm{ml}(20 \mu \mathrm{l}, 5 \mathrm{mg} / \mathrm{ml}$ in $96 \%$ ethanol). The amount of arachidonic acid added was calculated to ensure that substrate was not rate-limiting. Thus for a percentage conversion of only $0.1 \%$ the amount of PGF formed would be $10 \mu \mathrm{g} / \mathrm{g}$ tissue per $\mathrm{h}$, a value which greatly exceeded observed synthesis. Indomethacin $(4 \mu \mathrm{g} / \mathrm{ml})$ was added at the end of incubation.

The presence of $20 \mu 196 \%$ ethanol had no effect on PGF production.

Radioimmunoassay. Samples of incubation medium were assayed without extraction at three dilutions in duplicate and values were found to be parallel with the standard curve for PGF- $2 \alpha$. A total of 38 samples of incubation medium from all types of treatment were acidified, extracted with diethyl ether and then subjected to silicic acid column chromatography to obtain a partly purified PGF fraction, using the method of Kibbey, Bronn \& Minton (1977) except that cyclohexane was used instead of benzene. There was no significant difference between PGF values obtained before and after column chromatography (paired $t$ test, $P>0.05$ ) and this step was subsequently omitted.

Reconstituted residues or aliquots of incubation medium were measured for PGF using the assay conditions described by Mitchell, Flint \& Turnbull (1976) for 13,14-dihydro-15- 
oxo-PGF- $\alpha$ using $\left[5,6,9,11,15-{ }^{3} \mathrm{H}\right]$ prostaglandin $\mathrm{F}-2 \alpha$ as the radioligand. An antibody raised against PGF- $2 \alpha$ conjugated to bovine serum albumin at the $\mathrm{C}-1$ position was used (kindly provided by Professor E. W. Horton, Edinburgh) together with PGF- $2 \alpha$ standards. The cross-reactivities were very similar to those described previously for this PGF- $2 \alpha$ antibody (Dighe, Emslie, Henderson, Simon \& Rutherford, 1975); PGF-2 $\alpha$ and PGF-1 $\alpha$ were equally immunoreactive (100\% cross-reaction) and both prostaglandins gave identical displacement; PGF- $2 \beta$ gave a $57 \%$ cross-reaction (non-parallel). The antibody was used at a final dilution of $1 / 32000$ with $42-46 \%$ binding for the zero standard, and a sensitivity of $0.6 \mathrm{pg}$ PGF- $2 \alpha$ calculated as the value at a $10 \%$ drop in binding from the value recorded for zero concentration. The intra- and inter-assay coefficients of variation (\%) were $5.3 \pm 0.8$ and $9.1 \pm 0.2$, respectively.

\section{Steroid radioimmunoassays}

Progesterone was measured in peripheral plasma by the method described by Heap, Gwyn, Laing \& Walters (1973, method A) using antiserum 465 No. 6 (kindly provided by Dr B. J. A. Furr) which was raised in a goat immunized against progesterone conjugated to bovine serum albumin through the 11-position. The cross-reactivities of the antiserum have been reported by Sheldrick, Wright, Allen \& Heap (1977). Unconjugated oestradiol was measured using the conditions described by Challis, Heap \& Illingworth (1971) and antiserum 510 No. 5 (kindly provided by $\operatorname{Dr}$ B. J. A. Furr) which was raised in a goat immunized against oestradiol-17 $\beta$ conjugated to bovine serum albumin through the 6-position. Cross-reactivities of the antiserum have been reported by Heap \& Hamon (1979). All samples were measured in one batch. For progesterone the sensitivity of the assay was $7.7 \mathrm{pg}$, recovery $83.6 \%$ and intra-assay variation, $17.5 \%$. For oestradiol the sensitivity of the assay was $11.7 \mathrm{pg}$, recovery $90.0 \%$ and intra-assay variation, $3 \cdot 5 \%$.

\section{Statistical analysis}

To give a reliable indication of the variability between animals of the numerous variates observed, the means and standard errors in Tables 1-4 were calculated from within the respective treatment groups since the variate values for some groups, particularly for the control group, were often dramatically different from those of the remaining treatment groups, and the errors were thus likely to be heterogeneous.

The results of investigating the various treatment effects are summarized in Table 5. Denoting the treatments by the group designations, in the order in which they appear in Table 1, the effects presented in Table 5 were defined as follows:

$\begin{array}{ll}\text { Pregnancy } & \text { Group 2-Group 1 } \\ \text { Ovariectomy } & \text { Group 3-Group 1 } \\ \text { Oestradiol } & {[(\text { Group 4-Group 3) }+ \text { (Group 6-Group 5)]/2 }} \\ \text { Progesterone } & \text { [(Group 5-Group 3) + (Group 6-Group 4)]/2 } \\ \text { Oestradiol + progesterone } & {[\text { (Group 4-Group 3) }-(\text { Group 6-Group 5)]/2 }}\end{array}$

This partitioning has the advantage of identifying major treatment effects in an experimental design which involves multiple comparisons. Initial examination of the interaction between the oestradiol and progesterone treatments reveals whether the effect of one steroid treatment is reinforced or diminished by the presence of the second. Although this partitioning of the treatment effects facilitated interpretation for most variates the findings for $\beta$-glucuronidase should be regarded with some caution. The 'non-detectable' levels for Group 3 (control) on this variate had the effect of distorting the three orthogonal contrasts (oestradiol, progesterone and oestradiol $\times$ progesterone) and causing difficulties in interpretation (see Table 1 ). 
In compiling Table 6 the differences between the caruncular and the intercaruncular values of the variates were calculated for each animal, and the means and standard errors were calculated from the differences.

To examine the relative distances between the treatment groups, as gauged by the 16 variates taken collectively, a canonical variate analysis (Kendall \& Stuart, 1968) was carried out. This analysis selects the axis $\left(\mathrm{cv}_{1}\right)$ along which there is maximum separation between the groups, and the axis $\left(\mathrm{cv}_{2}\right)$ accounting for the maximum amount of the remaining separation. If the first two canonical variates account for the majority of the variation between groups then a 2-dimensional plot would give a fairly accurate representation of the 'distances' between the treatment groups. Because of the very large differences between Group 3 and the remaining groups, any analysis including the control animals would be dominated by these differences, possibly diminishing the discrimination (on the first 2 canonical variates) amongst the treated groups. For this reason the canonical variate analysis was carried out omitting Group 3. To lessen variate heterogeneity, original variables were transformed onto a logarithmic scale before analysis.

\section{Resuits}

There were no gross abnormalities of the reproductive tracts, judged by morphological appearance, an absence of luminal distension by excess fluid, and the recovery of uterine flushings which showed no visible evidence of infection. Blastocysts, judged to be normal by morphological and size criteria, were recovered from the uteri of all 4 ewes in Group $2 ; 1$ ewe had 2 blastocysts. Plasma concentrations of progesterone (mean \pm s.e.m.) in the jugular vein immediately before autopsy were $0.6 \pm 0.3,1.9 \pm 0.5,0.0,0.0,0.4 \pm 0.2$ and $0.4 \pm 0.1 \mathrm{ng} / \mathrm{ml}$ in Groups 1-6, respectively. Corresponding values for oestradiol-17 $\beta$ were $<12,<12,<12$, $19 \pm 4,<12$ and $19 \pm 3 \mathrm{pg} / \mathrm{ml}$.

\section{Effect of pregnancy and hormone treatments}

Results are presented as means ( \pm s.e.m.) for each group (Tables 1, 2, 3 and 4), and the statistical analysis is given in Table 5 .

Uterine weight. Uterine weight was reduced by ovariectomy $(P<0.001)$ and restored to values normal for intact animals by treatment with oestradiol-17 $\beta$. In contrast, progesterone treatment of ovariectomized animals, or the establishment of pregnancy in intact sheep had no significant effect (Table 1).

Protein concentration. Protein concentration of caruncular tissue was similar in all groups whereas that of intercaruncular tissue was significantly reduced by ovariectomy and restored to the values normal for intact animals by oestradiol treatment (Tables 1 and 5). No significant effects of hormone treatments were noted for the myometrium or skeletal muscle of ovariectomized ewes.

Protein synthesis. Incorporation of labelled leucine into TCA-precipitable protein was significantly higher in caruncular tissue of pregnant than of non-pregnant animals. Oestradiol treatment mimicked the effect of pregnancy in caruncular endometrium of ovariectomized animals, and increased leucine incorporation in myometrium. Progesterone had no significant effect (Tables 1 and 5). Leucine incorporation into skeletal muscle proteins was low and unaffected by hormone treatment (Table 1).

$\beta$-Glucuronidase and acid phosphatase. The activity of $\beta$-glucuronidase was similar in pregnant and non-pregnant sheep but was markedly reduced after ovariectomy in caruncular and intercaruncular tissues. Oestradiol treatment significantly increased activity in both tissues and myometrium (Tables 1 and 5). There was a significant negative interaction between oestradiol and progesterone treatments, indicating that while oestradiol increased $\beta$ glucuronidase activity, when given with progesterone the effect was abolished. 
Table 1. Effect of pregnancy, ovariectomy and steroid treatment on uterine weight, protein concentration and protein synthesis in uterine tissues $(\mathrm{C}=$ caruncular endometrium; $\mathrm{IC}=$ intercaruncular endometrium; $\mathbf{M}=$ myometrium) and skeletal muscle (S) of ewes

\begin{tabular}{|c|c|c|c|c|c|c|c|}
\hline \multirow[b]{2}{*}{ Variate } & & \multicolumn{2}{|c|}{ Intact } & \multicolumn{4}{|c|}{ Ovariectomized } \\
\hline & & $\begin{array}{c}\text { Group 1 } \\
\text { (non-pregnant) }\end{array}$ & $\begin{array}{c}\text { Group } 2 \\
\text { (pregnant) }\end{array}$ & $\begin{array}{l}\text { Group } 3 \\
\text { (control) }\end{array}$ & $\begin{array}{c}\text { Group } 4 \\
\text { (oestradiol) }\end{array}$ & $\begin{array}{c}\text { Group } 5 \\
\text { (progesterone) }\end{array}$ & $\begin{array}{c}\text { Group } 6 \\
\text { (oestradiol + } \\
\text { progesterone) }\end{array}$ \\
\hline No. of ewes & & 5 & 4 & 4 & 4 & 4 & 4 \\
\hline Liveweight (kg) & & $59.6 \pm 1.6$ & $62 \cdot 0 \pm 3 \cdot 0$ & $65.0 \pm 7.2$ & $62.0 \pm 4.6$ & $66.1 \pm 5.5$ & $62.9 \pm 6.0$ \\
\hline Uterine wt $(\mathrm{g})$ & & $55.8 \pm 5.8$ & $54 \cdot 7 \pm 7 \cdot 5$ & $17.3 \pm 6.3$ & $56.9 \pm 4.6$ & $29.3 \pm .4 .0$ & $53.5- \pm 4.8$ \\
\hline $\begin{array}{l}\text { Protein conc. } \\
(\mu \mathrm{g} / \mathrm{mg} \text { wet } \mathrm{wt})\end{array}$ & $\begin{array}{r}\mathrm{C} \\
\mathrm{IC} \\
\mathrm{M} \\
\mathrm{S}\end{array}$ & $\begin{array}{c}86.6 \pm 2.5 \\
86.6 \pm 2.7 \\
85.0 \pm 3.4 \\
{ }_{*}\end{array}$ & $\begin{array}{c}95.8 \pm 5.0 \\
94.5 \pm 5 \cdot 7 \\
89.0 \pm 4.0 \\
-\end{array}$ & $\begin{array}{r}70.5 \pm 7.5 \\
71.0 \pm 3.7 \\
103.3 \pm 9.6 \\
189.3 \pm 18.3\end{array}$ & $\begin{array}{r}97.5 \pm 4.6 \\
92.5 \pm 5.4 \\
80.5 \pm 10.6 \\
166.0 \pm 32.3\end{array}$ & $\begin{array}{r}103.5 \pm 18.6 \\
89.3 \pm 7.3 \\
89.8 \pm 6.0 \\
154.5 \pm 10.5\end{array}$ & $\begin{array}{r}98.0 \pm 6.4 \\
94.8 \pm 3.3 \\
97.5 \pm 7.4 \\
153.5 \pm 21.5\end{array}$ \\
\hline $\begin{array}{l}\text { Leucine incorporation } \\
\text { (nmol/mg protein) }\end{array}$ & $\begin{array}{r}\mathrm{C} \\
\mathrm{IC} \\
\mathrm{M} \\
\mathrm{S}\end{array}$ & $\begin{array}{c}10.3 \pm 0.9 \\
8.9 \pm 0.5 \\
5.3 \pm 0.6 \\
{ }^{*}\end{array}$ & $\begin{array}{c}14.7 \pm 0.9 \\
13.1 \pm 1.9 \\
6.8 \pm 0.9 \\
-\end{array}$ & $\begin{array}{l}6.4 \pm 1.0 \\
5.2 \pm 1.4 \\
3.3 \pm 0.6 \\
0.27 \pm 0.05\end{array}$ & $\begin{array}{l}13.1 \pm 3.1 \\
8.8 \pm 1.9 \\
7.3 \pm 2.1 \\
0.21 \pm 0.01\end{array}$ & $\begin{array}{l}5.6 \pm 1.4 \\
6.1 \pm 1.1 \\
2.6 \pm 0.6 \\
0.15 \pm 0.01\end{array}$ & $\begin{array}{l}9.3 \pm 0.8 \\
8.0 \pm 11.5 \\
4.3 \pm 1.2 \\
0.19 \pm 0.04\end{array}$ \\
\hline $\begin{array}{l}\beta \text {-Glucuronidase } \\
\text { (mmol/mg protein) }\end{array}$ & $\begin{array}{r}\mathrm{C} \\
\mathrm{IC} \\
\mathrm{M} \\
\mathrm{S}\end{array}$ & $\begin{array}{c}37.3 \pm 4.8 \\
14.3 \pm 2.4 \\
16.8 \pm 1.2\end{array}$ & $\begin{array}{c}34.6 \pm 3.5 \\
17.7 \pm 0.5 \\
17.1 \pm 1 \cdot 1 \\
-\end{array}$ & $\begin{array}{c}\text { n.d. } \\
\text { n.d. } \\
0.9 \stackrel{0}{ \pm} 0.5 \\
\text { n.d. }\end{array}$ & $\begin{array}{c}33.4 \pm 9.4 \\
17.9 \pm 2.5 \\
19.1 \pm 5.7 \\
\text { n.d. }\end{array}$ & $\begin{array}{r}24.3 \pm 6.2 \\
15.1 \pm 3.2 \\
8.4 \pm 3 \cdot 3 \\
\text { n.d. }\end{array}$ & $\begin{array}{c}26.7 \pm 2.1 \\
11.4 \pm 1.4 \\
11.2 \pm 2.5 \\
\text { n.d. }\end{array}$ \\
\hline $\begin{array}{l}\text { Acid phosphatase } \\
\text { (mmol/mg protein) }\end{array}$ & $\begin{array}{c}\mathrm{C} \\
\mathrm{IC} \\
\mathrm{M} \\
\mathrm{S}\end{array}$ & $\begin{array}{l}94.3 \pm 11 \cdot 3 \\
66 \cdot 0 \pm 8 \cdot 8 \\
28 \cdot 7 \pm 4 \cdot 4 \\
-\end{array}$ & $\begin{array}{c}81 \cdot 2 \pm 7 \cdot 1 \\
57 \cdot 6 \pm 5 \cdot 1 \\
27 \cdot 2 \pm 3 \cdot 8 \\
-\end{array}$ & $\begin{array}{r}102.4 \pm 22.0 \\
56.8 \pm 16.4 \\
31.2 \pm 9.7 \\
6.4 \pm 3.2\end{array}$ & $\begin{array}{r}45.5 \pm 1.4 \\
40.3 \pm 2.6 \\
41.1 \pm 5.8 \\
3.6 \pm 0.7\end{array}$ & $\begin{array}{l}81.8 \pm 11.9 \\
98.9 \pm 22.1 \\
49.7 \pm 15.4 \\
12.4 \pm 2.9\end{array}$ & $\begin{array}{r}85.1 \pm 12.3 \\
115.5 \pm 17.1 \\
44.3 \pm 11.8 \\
8.1 \pm 1.2\end{array}$ \\
\hline
\end{tabular}

Values are mean + s.e.m

* Not determined: n.d.. not detectable $(<0.35 \mathrm{nmol} / \mathrm{mg}$ protein $)$

Table 2. Effect of pregnancy, ovariectomy and steroid treatment on the metabolism (\% incorporation/ $300 \mathrm{mg}$ wet $\mathrm{wt})$ of androstenedione, oestrone and oestrone sulphate by uterine tissues $(\mathrm{C}=$ caruncular endometrium; $\mathrm{IC}=$ intercaruncular endometrium; $\mathrm{M}=$ myometrium) of ewes

\begin{tabular}{|c|c|c|c|c|c|c|c|}
\hline \multirow[b]{2}{*}{$\begin{array}{l}\text { Substrate and } \\
\text { fraction }\end{array}$} & & \multicolumn{2}{|c|}{ Intact } & \multicolumn{4}{|c|}{ Ovariectomized } \\
\hline & & $\begin{array}{c}\text { Group 1 } \\
\text { (non-pregnant) }\end{array}$ & $\begin{array}{c}\text { Group } 2 \\
\text { (pregnant) }\end{array}$ & $\begin{array}{l}\text { Group } 3 \\
\text { (control) }\end{array}$ & $\begin{array}{c}\text { Group 4 } \\
\text { (oestradiol) }\end{array}$ & $\begin{array}{c}\text { Group } 5 \\
\text { (progesterone) }\end{array}$ & $\begin{array}{c}\text { Group 6 } \\
\text { (oestradiol + } \\
\text { progesterone) }\end{array}$ \\
\hline $\begin{array}{l}\text { No. of ewes } \\
\text { Androstenedione }\end{array}$ & & 5 & 4 & 4 & 4 & 4 & 4 \\
\hline Ether-soluble & $\begin{array}{l}\mathrm{C} \\
\text { IC } \\
\mathrm{M}\end{array}$ & $\begin{array}{c}91.6 \pm 3.0 \\
92.3 \pm 2.1 \\
{ }^{*}\end{array}$ & $\begin{array}{c}92.9 \pm 4.8 \\
93.7 \pm 6 \cdot 1 \\
\text { — }^{*}\end{array}$ & $\begin{array}{l}90.6 \pm 4.8 \\
90.5 \pm 3.1 \\
90.6 \pm 2.9\end{array}$ & $\begin{array}{l}86.4 \pm 3.2 \\
83.2 \pm 2.8 \\
81.3 \pm 2.0\end{array}$ & $\begin{array}{l}85.3 \pm 8.4 \\
95.9 \pm 2.4 \\
96.4 \pm 2.3\end{array}$ & $\begin{array}{l}94.2 \pm 3.6 \\
90.2 \pm 5.8 \\
87.6 \pm 7.9\end{array}$ \\
\hline \multicolumn{8}{|l|}{ Oestrone } \\
\hline Ether-soluble & $\begin{array}{l}\mathrm{C} \\
\mathrm{IC} \\
\mathrm{M}\end{array}$ & $\begin{array}{c}60 \cdot 2 \pm 2 \cdot 5 \\
63 \cdot 1 \pm 1 \cdot 8 \\
\end{array}$ & $\begin{array}{c}62 \cdot 1 \pm 1 \cdot 5 \\
64 \cdot 1 \pm 3 \cdot 2 \\
\end{array}$ & $\begin{array}{l}41.7 \pm 3.8 \\
50.2 \pm 1.7 \\
49.4+1.0\end{array}$ & $\begin{array}{l}57 \cdot 3 \pm 1 \cdot 8 \\
65 \cdot 7 \pm 2 \cdot 8 \\
59 \cdot 8+4 \cdot 1\end{array}$ & $\begin{array}{l}40 \cdot 5 \pm 3.6 \\
47.8 \pm 4 \cdot 3 \\
48.8+4 \cdot 5\end{array}$ & $\begin{array}{l}48 \cdot 8 \pm 6 \cdot 6 \\
52 \cdot 6 \pm 5 \cdot 4 \\
45 \cdot 5 \pm 9 \cdot 4\end{array}$ \\
\hline Aqueous-soluble & $\begin{array}{r}\mathrm{C} \\
\mathrm{IC}\end{array}$ & $\begin{array}{l}30.5 \pm 2.0 \\
27.9 \pm 2.2\end{array}$ & $\begin{array}{l}35.7 \pm 3.7 \\
26.4 \pm 3.9\end{array}$ & $\begin{array}{l}40.9 \pm 5.2 \\
29.5 \pm 2.6\end{array}$ & $\begin{array}{l}31.7 \pm 1.6 \\
30.5 \pm 3.2\end{array}$ & $\begin{array}{l}40 \cdot 8 \pm 4.5 \\
28 \cdot 3 \pm 1 \cdot 6 \\
25 \cdot 5 \pm 1.2\end{array}$ & $\begin{array}{l}30.7 \pm 4.2 \\
30.4 \pm 0.6\end{array}$ \\
\hline Oestrone ${ }^{\dagger}$ & M & 二* & - & $\begin{array}{c}29.7 \pm 3 \cdot 5 \\
29.6 \pm 2.3\end{array}$ & $\begin{array}{c}32 \cdot 3 \pm 1.4 \\
32 \cdot 9 \pm 1 \cdot 3\end{array}$ & $\begin{array}{l}26.9 \pm 1 \cdot 1 \\
28.9 \pm 5.4\end{array}$ & $\begin{array}{c}26 \cdot 6 \pm 2 \cdot 6 \\
29 \cdot 0 \pm 12 \cdot 2 \\
(3)\end{array}$ \\
\hline Oestradiol-17 $17 \dagger$ & IC & - $^{*}$ & 一* & $3 \cdot 4 \pm 1 \cdot 1$ & $7 \cdot 1 \pm 2 \cdot 2$ & $4 \cdot 5 \pm 0.6$ & $3 \cdot 1 \pm 0.6$ \\
\hline \multicolumn{8}{|l|}{ Oestrone sulphate } \\
\hline Ether-soluble & $\begin{array}{r}\mathrm{C} \\
\mathrm{IC} \\
\mathrm{M}\end{array}$ & $\begin{array}{c}42.5 \pm 5.5 \\
39.9 \pm 4.5 \\
{ }^{*}\end{array}$ & $\begin{array}{c}50.7 \pm 2.7 \\
46.9 \pm 0.9 \\
{ }^{*}\end{array}$ & $\begin{array}{l}32 \cdot 1 \pm 3 \cdot 3 \\
37 \cdot 0 \pm 0.7 \\
39 \cdot 5 \pm 0.6\end{array}$ & $\begin{array}{l}39.6 \pm 1.2 \\
35.8 \pm 3.4 \\
39.7 \pm 1.4\end{array}$ & $\begin{array}{l}52 \cdot 3 \pm 5.2 \\
54 \cdot 1 \pm 3.0 \\
44.5 \pm 0.6\end{array}$ & $\begin{array}{l}30 \cdot 0 \pm 5 \cdot 0 \\
30 \cdot 1 \pm 4.9 \\
32 \cdot 1 \pm 4.5\end{array}$ \\
\hline Aqueous-soluble & IC & $\begin{array}{l}45 \cdot 2 \pm 3 \cdot 9 \\
44 \cdot 3 \pm 3 \cdot 7\end{array}$ & $\begin{array}{l}39 \cdot 4 \pm 4 \cdot 1 \\
43 \cdot 6 \pm 3 \cdot 1\end{array}$ & $\begin{array}{l}52.5 \pm 7.8 \\
45.5 \pm 1.8\end{array}$ & $\begin{array}{l}55.1 \pm 2.2 \\
60.8 \pm 3.0\end{array}$ & $\begin{array}{l}63.7 \pm 4.8 \\
64.5 \pm 4.5\end{array}$ & $\begin{array}{l}57.6 \pm 7.8 \\
55.4 \pm 6.7\end{array}$ \\
\hline Oestronet & IC & 二** & -* & $\begin{array}{l}47 \cdot 6 \pm 2.0 \\
29 \cdot 8+3 \cdot 2\end{array}$ & $\begin{array}{l}52.2 \pm 1.6 \\
24.7+3.0\end{array}$ & $\begin{array}{l}72 \cdot 0+4 \cdot 0 \\
27 \cdot 4+3 \cdot 9\end{array}$ & $\begin{array}{l}49 \cdot 0 \pm 5 \cdot 1 \\
23 \cdot 0+3 \cdot 5\end{array}$ \\
\hline Oestradiol-17 $\beta^{\dagger}$ & IC & -* & - & $2.4 \pm 0.5$ & $2.2 \pm 0.5$ & $1.8 \pm 0.7$ & $1.5 \pm 0.4$ \\
\hline
\end{tabular}

Values are mean \pm s.e.m.

+ Chromatographically identical to authentic unlabelled and ${ }^{14} \mathrm{C}$-labelled oestrone and oestradiol-17 $\beta$.

* Not determined. 
Acid phosphatase activity in the uterine tissues was similar in pregnant and non-pregnant sheep. Activity was not affected by ovariectomy, but subsequent progesterone treatment increased activity in the intercaruncular tissue. There was a significant statistical interaction between oestradiol and progesterone in caruncular tissue of ovariectomized ewes (Tables 1 and 5).

Steroid metabolism. The forms of steroid metabolism investigated were conjugation, hydrolysis and 17ß-oxidoreductase activity. Androstenedione metabolism was low in the uterine tissues (Table 2). The amount of unmetabolized $\left[{ }^{3} \mathrm{H}\right]$ androstenedione recovered after incubation with intercaruncular tissue was $71.4 \pm 4.5,77.9 \pm 3.2,99.1 \pm 0.6$ and $89.6 \pm 10.4 \%$ in Groups $3,4,5$ and 6, respectively. Radioactivity recovered in a phenolic fraction (Groups 3, 4 and $5 ; 1 \cdot 2 \pm 0 \cdot 1 \%$ ) was too low for definitive identification.

Oestrone was metabolized substantially to an aqueous soluble form(s) (Table 2). Percentage conversion was similar in pregnant and non-pregnant animals (Table 5). Recovery of radioactivity from tissue of ovariectomized animals was less satisfactory, but results indicated that ovariectomy decreased significantly the levels of labelled compounds in the ether-soluble fraction (Tables 2 and 5). Oestradiol treatment restored levels in the ether-soluble fraction to those found in intact animals.

Oestrone sulphate metabolism was similar in caruncular and intèrcaruncular tissue of animals in Groups 1,2 and 3. After steroid treatment of ovariectomized ewes there was a significant negative interaction between oestradiol and progesterone in the amount of ether-soluble radioactivity in caruncular and intercaruncular tissue, and of aqueous-soluble radioactivity in intercaruncular tissue. In contrast to an absence of treatment effect on myometrial metabolism of androstenedione or oestrone, progesterone treatment resulted in significantly greater activity in the aqueous fraction of oestrone sulphate incubations, while oestradiol and progesterone showed a marked negative interaction (Tables 2 and 5).

Prostaglandin $F$. There was a significant effect of pregnancy and steroid hormones on PGF production (Tables 3, 4 and 5).

Table 3. Effect of pregnancy, ovariectomy and steroid treatment on the net release $(\mathrm{ng} / \mathrm{g}$ wet $\mathrm{wt} / \mathrm{h})$ of prostaglandin $\mathrm{F}$ by uterine tissues $(\mathrm{C}=$ caruncular endometrium; $\mathrm{IC}=$ intercaruncular endometrium; $\mathrm{M}=$ myometrium) of ewes

\begin{tabular}{|c|c|c|c|c|c|c|c|}
\hline \multirow[b]{2}{*}{ Variate } & & \multicolumn{2}{|c|}{ Intact } & \multicolumn{4}{|c|}{ Ovariectomized } \\
\hline & & $\begin{array}{c}\text { Group } 1 \\
\text { (non-pregnant) }\end{array}$ & $\begin{array}{c}\text { Group } 2 \\
\text { (pregnant) }\end{array}$ & $\begin{array}{l}\text { Group } 3 \\
\text { (control) }\end{array}$ & $\begin{array}{c}\text { Group } 4 \\
\text { (oestradiol) }\end{array}$ & $\begin{array}{l}\text { Group } 5 \\
\text { (progesterone) }\end{array}$ & $\begin{array}{c}\text { Group } 6 \\
\text { (oestradiol + } \\
\text { progesterone) }\end{array}$ \\
\hline No. of ewes & & 5 & 4 & 4 & 4 & 4 & 4 \\
\hline \multirow{3}{*}{$\begin{array}{l}\text { Basal release } \\
\text { (indomethacin. } \\
4 \mu \mathrm{g} / \mathrm{ml} \text { ) }\end{array}$} & C & $30.6 \pm 10.8$ & $129.8 \pm 12.8$ & $25 \cdot 3 \pm 3 \cdot 1$ & $1.5 \pm 1.2$ & $73.4 \pm 41.0$ & $54.8 \pm 23.9$ \\
\hline & $1 C$ & $25.8 \pm 10.0$ & $50.6 \pm 15.2$ & $58.2 \pm 5.3$ & $9.7 \pm 2.9$ & $51.1 \pm 30.9$ & $25.5 \pm 14.7$ \\
\hline & $\mathbf{M}$ & $6.9 \pm 3.3$ & $18.6 \pm 4.2$ & $30 \cdot 0 \pm 11.7$ & $18.4 \pm 7.3$ & $17 \cdot 3 \pm 4 \cdot 8$ & $13.8 \pm 4.9$ \\
\hline \multirow{3}{*}{$\begin{array}{l}\text { Net production } \\
\text { (no indomethacin) }\end{array}$} & C & $165.0 \pm 13.0$ & $92.4 \pm 10.6$ & $148 \cdot 5 \pm 22 \cdot 0$ & $54.4 \pm 29.0$ & $164.9 \pm 10.7$ & $102.8 \pm 32.3$ \\
\hline & IC & $47.8 \pm 3.5$ & $96.9 \pm 36.5$ & $109.4 \pm 27.2$ & $45.6 \pm 4.6$ & $69.0 \pm 8.5$ & $81 \cdot 0 \pm 17 \cdot 1$ \\
\hline & $\mathbf{M}$ & $57.7 \pm 11.3$ & $71.6 \pm 12.9$ & $141 \cdot 8 \pm 15 \cdot 8$ & $86 \cdot 1 \pm 12.7$ & $78.5 \pm 9.5$ & $77.6 \pm 21 \cdot 1$ \\
\hline \multirow{3}{*}{$\begin{array}{l}\text { Maximum production } \\
\text { (arachidonic acid } \\
20 \mu \mathrm{g} / \mathrm{ml})\end{array}$} & C & $268 \cdot 2 \pm 5 \cdot 1$ & $309.1 \pm 25.5$ & $353 \cdot 2 \pm 51 \cdot 4$ & $404 \cdot 1 \pm 54 \cdot 1$ & $410 \cdot 1 \pm 74 \cdot 3$ & $441 \cdot 6+28 \cdot 8$ \\
\hline & IC & $185 \cdot 8 \pm 14.5$ & $247.0 \pm 31.1$ & $139.2 \pm 26.5$ & $226.6 \pm 10.4$ & $235.9 \pm 29.5$ & $252.8 \pm 17.9$ \\
\hline & $M$ & $221 \cdot 5 \pm 33 \cdot 2$ & $185.3 \pm 17.2$ & $177.3 \pm 9.0$ & $219.1 \pm 42.9$ & $209.0 \pm 36.9$ & $244.9 \pm 25.7$ \\
\hline
\end{tabular}

Values are mean \pm s.e.m.

Values were significantly higher in the caruncular tissue of pregnant than in non-pregnant animals (Table 4). The basal release of PGF from caruncular tissue incubated in the presence of indomethacin was significantly increased by pregnancy and was raised by progesterone treatment of ovariectomized animals. Basal release from intercaruncular tissue was reduced significantly by oestradiol treatment (Tables 3 and 5).

The net production of PGF was lower in caruncular tissue of pregnant than of non-pregnant animals, and of oestradiol-treated ovariectomized sheep compared with ovariectomized animals. 
Table 4. Effect of pregnancy on prostaglandin $F$ concentration ( $\mathrm{ng} / \mathrm{g}$ wet $\mathrm{wt})$ in uterine tissues $(\mathrm{C}=$ caruncular endometrium; IC $=$ intercaruncular endometrium; $\mathbf{M}=$ myometrium) of 3 non-pregnant and 4 pregnant ewes

\begin{tabular}{llcc}
\hline Tissue & Incubation* & $\begin{array}{c}\text { Group 1 } \\
\text { (non-pregnant) }\end{array}$ & $\begin{array}{c}\text { Group 2 } \\
\text { (pregnant) }\end{array}$ \\
\hline C & Before & $48 \pm 18$ & $213 \pm 24^{* * *}$ \\
& After & $9 \pm 3$ & $34 \pm 9$ \\
IC & Before & $47 \pm 18$ & $63 \pm 23$ \\
& After & n.d. & n.d. \\
M & Before & $19 \pm 6$ & $31 \pm 9$ \\
& After & n.d. & n.d. \\
\hline
\end{tabular}

Values are mean \pm s.e.m.; n.d., not detectable.

* At $37^{\circ} \mathrm{C}$ for $90 \mathrm{~min}$ in presence of $4 \mu \mathrm{g}$ indomethacin $/ \mathrm{ml}$.

*** Significantly different from value for non-pregnant animals, $P<0.001$.

Table 5. Statistical significance of mean effect ( \pm s.e.m.) of pregnancy, or of ovariectomy and steroid treatments (see text) on protein concentration, protein synthesis, steroid metabolism and prostaglandin $\mathrm{F}$ production by uterine tissues $(\mathrm{C}=$ caruncular endometrium; $\mathrm{IC}=$ intercaruncular endometrium; $\mathbf{M}=$ myometrium)

\begin{tabular}{|c|c|c|c|c|c|c|}
\hline \multirow[b]{2}{*}{ Variate } & \multirow[b]{2}{*}{ Tissue } & \multicolumn{5}{|c|}{ Treatment } \\
\hline & & Pregnancy & Ovariectomy & Oestradiol & Progesterone & $\begin{array}{l}\text { Oestradiol + } \\
\text { progesterone }\end{array}$ \\
\hline \multirow{3}{*}{$\begin{array}{l}\text { Protein conc. } \\
\qquad(\mu \mathrm{g} / \mathrm{mg} \text { wet } w \mathrm{t})\end{array}$} & C & - & - & - & - & - \\
\hline & IC & - & $15 \cdot 6 \pm 4 \cdot 6^{*}$ & $13 \cdot 5 \pm 5 \cdot 2^{*}$ & - & - \\
\hline & M & - & - & & - & - \\
\hline \multirow{3}{*}{$\begin{array}{l}\text { Leucine incorporation } \\
\text { (nmol/mg protein) }\end{array}$} & $\mathrm{C}$ & $4.4 \pm 1 \cdot 3^{*}$ & - & $5 \cdot 2 \pm 1 \cdot 8^{*}$ & - & - \\
\hline & IC & $=$ & - & - & - & - \\
\hline & $\mathbf{M}$ & - & $\overline{0}$ & $2 \cdot 9 \pm 1 \cdot 3^{*}$ & - & - \\
\hline \multirow{2}{*}{$\begin{array}{l}\text { B-Glucuronidase } \\
\text { (mmol/mg) }\end{array}$} & C & 二 & $-35 \cdot 8 \pm 4 \cdot 8^{* * *}$ & $17 \cdot 9 \pm 5 \cdot 7^{*}$ & - & $-15 \cdot 5 \pm 5 \cdot 7^{*}$ \\
\hline & $\begin{array}{l}\text { IC } \\
\text { M }\end{array}$ & Z & $\begin{array}{l}-14.3 \pm 2.4^{* * * *} \\
-15 \cdot 1+0.4^{* * *}\end{array}$ & $\begin{array}{r}7 \cdot 1 \pm 2 \cdot 1^{* *} \\
10 \cdot 5 \pm 3 \cdot 5^{* *}\end{array}$ & - & $\begin{array}{c}-10 \cdot 8 \pm 2.1^{* * *} \\
-7.7 \pm 3.5^{*}\end{array}$ \\
\hline \multirow{3}{*}{$\begin{array}{l}\text { Acid phosphatase } \\
(\mathrm{mmol} / \mathrm{mg})\end{array}$} & $\mathrm{C}$ & - & - & - & - & $30 \cdot 1 \pm 14 \cdot 0^{*}$ \\
\hline & IC & - & - & - & $58 \cdot 7 \pm 16 \cdot 3^{* * *}$ & - \\
\hline & M & - & - & - & - & - \\
\hline \multirow{3}{*}{$\begin{array}{l}\text { Androstenedione, } \\
\text { ether-soluble } \\
\text { (\% incorporation) }\end{array}$} & C & - & - & - & - & - \\
\hline & IC & - & - & - & - & - \\
\hline & $\mathbf{M}$ & - & - & - & - & - \\
\hline \multirow{3}{*}{$\begin{array}{l}\text { Oestrone, ether-soluble } \\
\text { (\% incorporation) }\end{array}$} & $\mathrm{C}$ & - & $-18 \cdot 5 \pm 4 \cdot 5^{* *}$ & $12 \cdot 0 \pm 4 \cdot 3^{* *}$ & - & - \\
\hline & IC & - & $-12.9 \pm 2.5^{* *}$ & $10.2 \pm 3.8^{* *}$ & - & - \\
\hline & $\mathbf{M}$ & n.d. & n.d. & $=$ & - & - \\
\hline \multirow{3}{*}{$\begin{array}{l}\text { Oestrone, aqueous- } \\
\text { soluble } \\
\text { (\% incorporation) }\end{array}$} & C & - & - & - & - & - \\
\hline & IC & - & - & - & - & - \\
\hline & $\mathbf{M}$ & n.d. & n.d. & - & - & - \\
\hline \multirow{3}{*}{$\begin{array}{l}\text { Oestrone } \mathrm{SO}_{4}, \\
\text { ether-soluble } \\
\text { (\% incorporation) }\end{array}$} & C & - & - & - & - & $-14.9 \pm 4.0^{* *}$ \\
\hline & IC & - & - & $-12 \cdot 6 \pm 3 \cdot 4^{* *}$ & - & $-11 \cdot 4 \pm 3 \cdot 4^{*}$ \\
\hline & $\mathbf{M}$ & n.d. & n.d. & - & - & 二 \\
\hline \multirow{3}{*}{$\begin{array}{l}\text { Oestrone } \mathrm{SO}_{4} \text {, } \\
\text { aqueous-soluble } \\
\text { (\% incorporation) }\end{array}$} & C & - & - & - & - & - \\
\hline & IC & - & - & - & - & $-12 \cdot 2 \pm 4.4^{*}$ \\
\hline & $\mathbf{M}$ & n.d. & n.d. & $-9 \cdot 2 \pm 3 \cdot 5^{*}$ & $10 \cdot 6 \pm 3 \cdot 5^{*}$ & $-13.8 \pm 3.5^{* *}$ \\
\hline \multirow{3}{*}{$\begin{array}{l}\text { PGF, basal release } \\
(\mathrm{ng} / \mathrm{g} / \mathrm{h})\end{array}$} & $\mathrm{C}$ & $99.1 \pm 16.7^{* * *}$ & - & 二 & 二 & 二 \\
\hline & IC & 二 & - & $-37 \cdot 1 \pm 17 \cdot 4^{*}$ & - & - \\
\hline & $\mathbf{M}$ & - & - & - & - & - \\
\hline \multirow{3}{*}{$\begin{array}{l}\text { PGF, net production } \\
(\mathrm{ng} / \mathrm{g} / \mathrm{h})\end{array}$} & C & $-72 \cdot 6 \pm 16 \cdot 8^{* *}$ & - & $-78 \cdot 1 \pm 24 \cdot 9^{* *}$ & - & - \\
\hline & IC & $=$ & - & 二 & - & - \\
\hline & $\mathbf{M}$ & - & - & - & $-35.9 \pm 15.4^{*}$ & - \\
\hline \multirow{3}{*}{$\begin{array}{l}\text { PGF, maximum } \\
\text { production } \\
(\mathrm{ng} / \mathrm{g} / \mathrm{h})\end{array}$} & $\mathrm{C}$ & 一 & - & - & - & - \\
\hline & IC & - & - & $52 \cdot 2 \pm 22 \cdot 4^{*}$ & $61.5 \pm 22.4^{*}$ & - \\
\hline & $\mathbf{M}$ & - & - & - & - & - \\
\hline
\end{tabular}


The absence of an interaction effect between oestradiol and progesterone treatments indicates that oestradiol administration reduced the net production of PGF in both the presence and absence of progesterone. There was no significant effect of pregnancy and hormone treatment for the intercaruncular tissue (Table 5). Net production by myometrial tissue was increased by ovariectomy (Table 3) but was reduced to normal values by progesterone treatment (Table 5).

PGF production in all incubations was greatly enhanced by the presence of arachidonic acid (Table 3). An effect of hormone treatment was only significant for intercaruncular tissue from oestrogen- or progesterone-treated animals compared with those in Group 3 (Table 5). Since the interaction between oestradiol and progesterone was not significant, the data indicate that the hormones had an additive effect on the maximum production of PGF in intercaruncular tissue.

\section{Differential responses of caruncular and intercaruncular endometrial tissue to pregnancy and hormone treatments}

Because the results in Tables 1-5 indicated that the responses of the various tissues differed according to treatment, statistical comparisons were made to ascertain the significance of the differences (Table 6).

Protein concentration and synthesis, and oestrone sulphate metabolism were similar in all groups, while $\beta$-glucuronidase, all measurements of PGF and the metabolism of androstenedione generally showed greater responses in the caruncular than the intercaruncular tissues.

The higher basal release of PGF by caruncular tissue of pregnant animals reflected initial tissue concentrations and a significant amount of residual PGF was found in the caruncles of pregnant animals after incubation (Tables 3 and 4). The net production of PGF was significantly higher in the caruncular tissue of non-pregnant or ovariectomized ewes treated with progesterone while the maximum production was greater in all treatment groups although the difference was only significant in non-pregnant and ovariectomized ewes treated with oestradiol and progesterone (Table 6). Oestrogen treatment of ovariectomized ewes produced no

Table 6. Comparison of the effect of pregnancy, ovariectomy and steroid treatment on protein concentration, protein synthesis, enzyme activities, and prostaglandin F (PGF) production between caruncular

(C) and intercaruncular (IC) endometrium of sheep

\begin{tabular}{|c|c|c|c|c|c|c|}
\hline \multirow[b]{2}{*}{ Variate } & \multicolumn{2}{|c|}{ Intact } & \multicolumn{4}{|c|}{ Ovariectomized } \\
\hline & $\begin{array}{c}\text { Group l } \\
\text { (non-pregnant) }\end{array}$ & $\begin{array}{c}\text { Group 2 } \\
\text { (pregnant) }\end{array}$ & $\begin{array}{l}\text { Group } 3 \\
\text { (control) }\end{array}$ & $\begin{array}{c}\text { Group 4 } \\
\text { (oestradiol) }\end{array}$ & $\begin{array}{c}\text { Group S } \\
\text { (progesterone) }\end{array}$ & $\begin{array}{c}\text { Group 6 } \\
\text { (oestradiol + } \\
\text { progesterone) }\end{array}$ \\
\hline No. of ewes & 5 & 4 & 4 & 4 & 4 & 4 \\
\hline Protein conc. $(\mu \mathrm{g} / \mathrm{mg})$ & $0.1 \pm 2.1$ & $1.3 \pm 2.7$ & $2.5 \pm 0.5$ & $5.0 \pm 3.5$ & $14 \cdot 3 \pm 24 \cdot 3$ & $3 \cdot 3+6 \cdot 6$ \\
\hline $\begin{array}{l}\text { Protein synthesis } \\
\text { (nmol/mg protein) }\end{array}$ & $1.3 \pm 0.7$ & $1.6 \pm 1.8$ & $1.2 \pm 1.2$ & $3.3 \pm 1.2$ & $-0.5 \pm 0.7$ & $1.3 \pm 1.7$ \\
\hline $\begin{array}{l}\text { B-Glucuronidase } \\
\text { (mmol/mg protein) }\end{array}$ & $22.9 \pm 4.2$ & $17.0 \pm 3.2$ & $1.4 \pm 1.4$ & $15 \cdot 6 \pm 7.1$ & $9.3 \pm 7.2$ & $15 \cdot 3 \pm 3 \cdot 2$ \\
\hline $\begin{array}{l}\text { Acid phosphatase } \\
\text { (mmol/mg protein) }\end{array}$ & $28 \cdot 2 \pm 12 \cdot 3$ & $23 \cdot 6 \pm 11 \cdot 2$ & $67.4 \pm 23 \cdot 8$ & $5.2 \pm 1.6$ & $-17.2 \pm 30.5$ & $-30.4 \pm 13.7$ \\
\hline \multicolumn{7}{|c|}{ Androstenedione (\% incorporation) } \\
\hline $\begin{array}{l}\text { Ether-soluble } \\
\text { Aqueous-soluble }\end{array}$ & $\begin{array}{r}-0.70 \pm 2.35 \\
1.56 \pm 0.44\end{array}$ & $\begin{array}{r}-0.85 \pm 2.58 \\
1.90 \pm 0.78\end{array}$ & $\begin{array}{l}0.03 \pm 2.21 \\
1.83 \pm 2.09\end{array}$ & $\begin{array}{r}3.33 \pm 0.98 \\
-0.53 \pm 0.31\end{array}$ & $\begin{array}{r}-10.58 \pm 7.14 \\
1.43 \pm 1.01\end{array}$ & $\begin{array}{l}4 \cdot 00 \pm 2 \cdot 23 \\
2 \cdot 60 \pm 2 \cdot 16\end{array}$ \\
\hline \multicolumn{7}{|l|}{ Oestrone (\% incorporation) } \\
\hline $\begin{array}{l}\text { Ether-soluble } \\
\text { Aqueous-soluble }\end{array}$ & $\begin{array}{r}-2.92 \pm 1.34 \\
2.62 \pm 1.96\end{array}$ & $\begin{array}{r}-1.98 \pm 2.33 \\
9.35 \pm 6.51\end{array}$ & $\begin{array}{r}-8.48 \pm 4.65 \\
11.38 \pm 6.79\end{array}$ & $\begin{array}{r}-8.45 \pm 1.52 \\
1.18 \pm 3.96\end{array}$ & $\begin{array}{r}-7.28 \pm 1.47 \\
2.85 \pm 2.43\end{array}$ & $\begin{array}{r}-3.75 \pm 2.19 \\
4.28 \pm 4.05\end{array}$ \\
\hline \multicolumn{7}{|c|}{ Oestrone $\mathrm{SO}_{4}$ ( $\%$ incorporation) } \\
\hline $\begin{array}{l}\text { Ether-soluble } \\
\text { Aqueous-soluble }\end{array}$ & $\begin{array}{l}1.53 \pm 0.92 \\
0.90 \pm 1.23\end{array}$ & $\begin{array}{r}3.80 \pm 2.53 \\
-4.25 \pm 2.10\end{array}$ & $\begin{array}{r}-4.90 \pm 3.25 \\
6.98 \pm 9.00\end{array}$ & $\begin{array}{r}3.78 \pm 3.86 \\
-5.70 \pm 2.26\end{array}$ & $\begin{array}{l}-1.75 \pm 8.15 \\
-0.75 \pm 9.25\end{array}$ & $\begin{array}{r}-0.13 \pm 1.08 \\
2 \cdot 20 \pm 2.84\end{array}$ \\
\hline \multicolumn{7}{|l|}{ PGF (ng/g/h) } \\
\hline Basal release & $4.8 \pm 5.4$ & $79.1 \pm 22.5$ & $-31.0 \pm 4.4$ & $-8.2 \pm 2.5$ & $22 \cdot 3 \pm 38 \cdot 1$ & $29 \cdot 3 \pm 33 \cdot 0$ \\
\hline Net production & $117.2 \pm 9.5$ & $-4 \cdot 5 \pm 35 \cdot 1$ & $14.5 \pm 5.8$ & $8.8 \pm 32.7$ & $95.9 \pm 10.0$ & $21.8 \pm 44.9$ \\
\hline Maximum production & $82.3 \pm 17.1$ & $62.1 \pm 50.3$ & $188.7 \pm 56.8$ & $117.5 \pm 64.3$ & $174.3 \pm 52.9$ & $188.9 \pm 19.5$ \\
\hline
\end{tabular}

Values represent the mean difference $( \pm$ s.e.m.) between caruncular tissue value minus intercaruncular tissue value; bold type indicates that the difference is statistically significant $(P<0 \cdot 05)$. 
differential effects in any of the PGF parameters, but progesterone treatment increased net production in caruncular endometrium.

An effect of oestrogen treatment on oestrone metabolism was greater in intercaruncular tissue but was observed only in the ether-soluble fraction and was not reflected in a significant decrease in the aqueous-soluble fraction. The progesterone effect on acid phosphatase in intercaruncular tissue was significant.

Comparisons of the 3 uterine tissues showed relatively lower activities in myometrium for protein synthesis, $\beta$-glucuronidase, and phosphatase and the PGF measurements but steroid metabolism was similar in all 3 tissues.
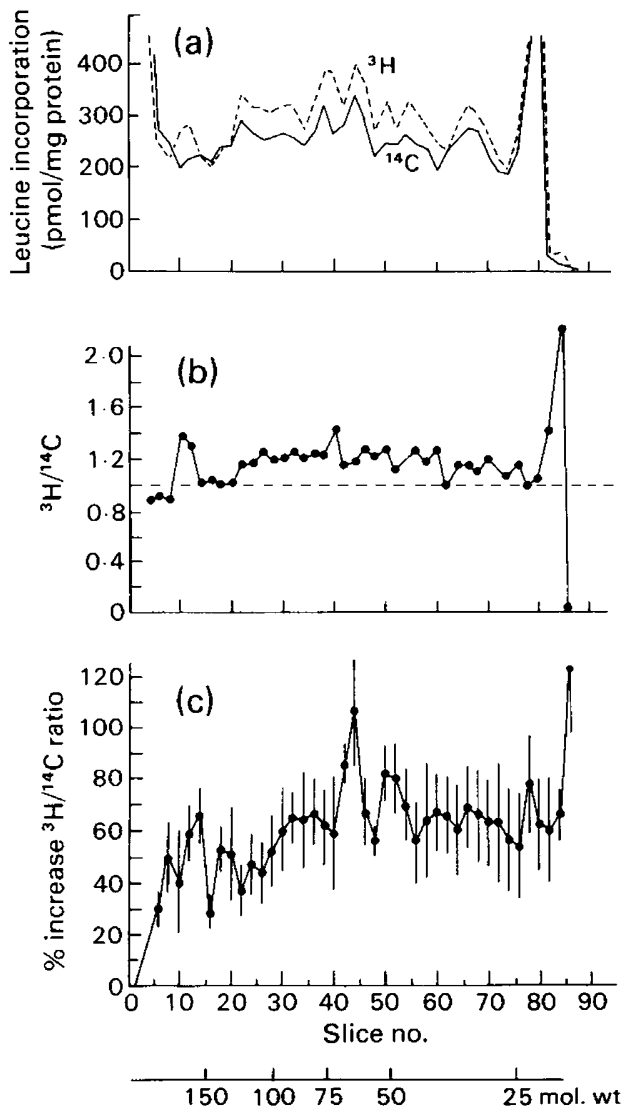

Text-fig. 1. Protein synthesis in caruncular endometrium of pregnant and non-pregnant sheep on Day 15 measured by incorporation of $\left[{ }^{3} \mathrm{H}\right]$ leucine (pregnant) or $\left[{ }^{14} \mathrm{C}\right]$ leucine (non-pregnant) into tissue proteins. After incubation of tissue with labelled amino acid, samples of ${ }^{3} \mathrm{H}$-labelled and ${ }^{14} \mathrm{C}$-labelled proteins were treated as described in the text and aliquots of each were applied to the same $10 \%$ polyacrylamide gel containing $0 \cdot 1 \%$ sodium dodecyl sulphate. Electrophoresis was carried out for $4 \mathrm{~h}$ at $3 \mathrm{~mA}$, and the gel was then frozen and cut into $1 \mathrm{~mm}$ slices. The results show (a) higher incorporation of leucine in caruncular endometrium of a pregnant (-- ) than of a non-pregnant (-) animal in most regions of the gel; (b) small changes in ${ }^{3} \mathrm{H} /{ }^{14} \mathrm{C}$ ratio identified in profiles from an individual animal; (c) mean ( \pm s.e.m.) values of leucine incorporation into proteins in 4 pairs of animals (4 pregnant and 4 non-pregnant) calculated as $\%$ increase in ${ }^{3} \mathrm{H} /{ }^{14} \mathrm{C}$ ratio above background in gel slices 1 and 2 (Mayol, 1975). A peak of radioactivity was detected consistently in all pregnant animals in proteins with a molecular weight of $>150000$ (gel slices 10-12). The gel was calibrated with molecular weight markers of 53000 to 265000 . The tracker dye (bromophenol blue) was recovered in gel slices $85-87$. 


\section{Electrophoretic profiles of protein synthesis}

The distribution of radioactivity and ${ }^{3} \mathrm{H} /{ }^{14} \mathrm{C}$ ratios on PAGE gels provided evidence for an overall increase in the incorporation of leucine into proteins in caruncular tissue from pregnant or oestrogen-treated animals, and for the synthesis of specific proteins (Text-fig. 1). The pattern of protein synthesis was similar for caruncular and intercaruncular tissues in pregnant and non-pregnant ewes when examined at both the high and low molecular weight ranges. In all 4 pregnant animals, however, a peak of radioactivity was detected in caruncular tissue proteins with a molecular weight of $>150000$ (Text-fig. 1c). Blastocyst tissue incorporated labelled leucine $(30.4 \pm 7.3$ (s.e.m.) $\mathrm{nmol} / \mathrm{mg}$ protein; $n=4)$ at $2-3$ times the rate of endometrial tissues. The distribution of radioactivity of blastocysts was similar after electrophoresis to that of the endometrium.

\section{Canonical variate analysis}

The 16 variates used for analysis were uterine weight; protein concentration; $\beta$ glucuronidase and acid phosphatase activities (expressed as $\mathrm{mmol} / \mathrm{mg}$ tissue and $\mathrm{mmol} / \mathrm{mg}$ protein); leucine incorporation; androstenedione, oestrone and oestrone sulphate conversion (ether-soluble and aqueous-soluble steroids); and PG basal release, net production and maximum production. The spatial distribution of each animal fell into 5 clearly delineated groups when represented in 2 dimensions by canonical variates, $\mathrm{cv}_{1}$ and $\mathrm{cv}_{2}$ (Text-fig. 2). In caruncular tissue, the responses in Groups 1 and 2 were relatively close and Group 6 was also close by. In intercaruncular tissue, the tissue responses in Groups 1 and 2 differed particularly in respect of $\mathrm{cv}_{1}$, and were mimicked most closely by those of Group 4 (Text-fig. 2).
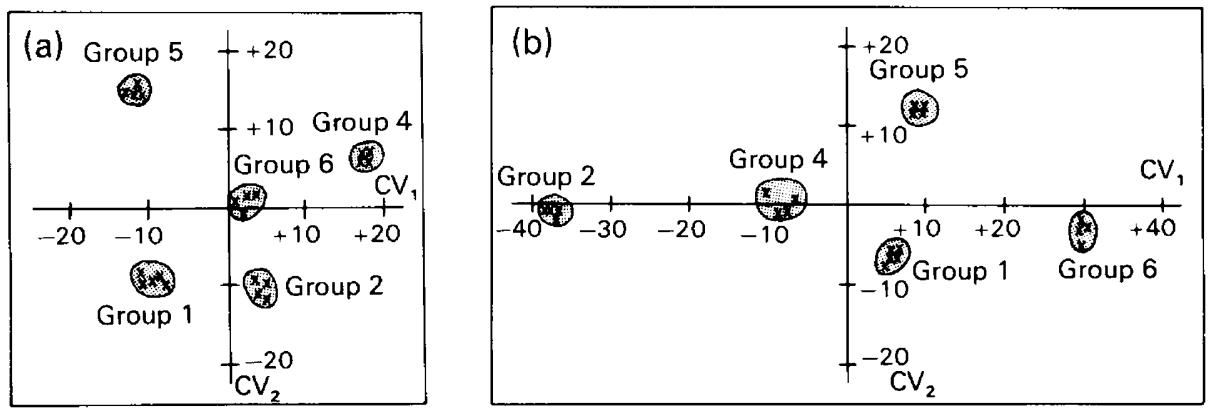

Text-fig. 2. Canonical variate analysis after logarithmic transformation of protein concentration, rate of protein synthesis, $\beta$-glucuronidase and acid phosphatase activities, steroid metabolism and dynamics of prostaglandin $F$ production by (a) caruncular and (b) intercaruncular endometrium in sheep in Groups $1,2,4,5$ and 6 (see text). $\mathrm{cv}_{1}$, first canonical variate; $\mathrm{cv}_{2}$, second canonical variate.

\section{Discussion}

Among the endometrial factors examined in this study, few were affected by the presence of an embryo at Day 15 of gestation. Evidence was obtained for an effect of the preimplantation embryo on caruncular, and to a lesser extent on intercaruncular tissue in respect of the rate of protein synthesis as measured by the incorporation of radiolabelled leucine into acid-soluble protein. This increased synthesis of proteins agrees with a reported increase in protein content of uterine flushings between Days 13 and 18 of pregnancy (Roberts et al., 1976; Ellinwood, Nett \& Niswender, 1979). Electrophoretic studies of newly synthesized protein in 2 endometrial tissues revealed an increase in high-molecular weight proteins associated with pregnancy or oestradiol 
treatment. This contrasts with earlier results on uterine flushings in which 10 uterine-specific protein bands were located on Day 15, of which 5 were pregnancy-specific (Roberts et al., 1976). An explanation for the difference between these results may lie in the techniques applied (isoelectric focussing, Roberts et al., 1976; SDS-PAGE size separation, present study), or in the failure of the technique used to resolve labelled proteins destined for export; the majority of proteins labelled were confined to tissue and were not recovered in the supernatant.

The increase in the protein synthetic capacity of the endometrium on Day 15 of pregnancy or after oestradiol treatment may reflect an increase in blood flow at that time. Both oestradiol-17ß (Greiss \& Miller, 1971; Anderson, Hackshaw, Still \& Greiss, 1977) and the presence of a conceptus (Greiss \& Anderson, 1970) increased uterine blood flow at Days 13-15 of pregnancy in sheep. There is evidence that the conceptus exerts a local effect on vasculature in the endometrium particularly by inhibiting the response of arterial smooth muscle cells to neurotransmitters resulting in uterine vasodilatation (Ford, Weber \& Stormshak, 1977; Pope \& Stormshak, 1979). However, it seems unlikely from this study that the preimplantation embryo influences steroid metabolism in the endometrium to bring about a local increase in oestradiol-17 13 , since there is so far no evidence from in-vitro studies that ovine trophoblast has significant aromatase activity (Gadsby et cl., 1980; H.-O. Hoppen \& J. K. Findlay, unpublished observations). Uterine tissues from pregnant or non-pregnant ewes, or from ovariectomized ewes treated with ovarian steroids, showed negligible metabolism of androstenedione to phenolic compounds, a finding noted previously (Rossier \& Pierrepoint, 1974; Miller, Murphy \& Stone, 1977; Murphy, Stone, Miller \& Moore, 1977; Stone, Murphy \& Miller, 1978). There was a significant amount of oestrone converted to aqueous-soluble compounds, and of oestrone sulphate metabolized to ether-soluble compounds, indicative of sulphotransferase and arylsulphatase, respectively. However, no localized differences were observed between caruncular and intercaruncular tissues in pregnant or non-pregnant animals.

In addition to the effect on protein synthesis in the endometrium, there was evidence for a localized change in the dynamics of prostaglandin $\mathrm{F}$ metabolism associated with the presence of an embryo. By Day 15 the concentration of PGF in caruncular tissue was much greater than that in intercaruncular tissue of pregnant animals, or in both tissues of non-pregnant animals. This finding is consistent with that of Ellinwood et al. (1979) who found that PGF-2 $\alpha$ concentrations in endometrial tissue were significantly greater on Day 15 (but not Days 13 or 17) in pregnant than in non-pregnant animals. The absolute values obtained by these workers were approximately twice those found here, a difference possibly related to the time taken in the separation of the tissues in our study. A localized effect of the preimplantation embryo was also seen in the higher basal release and a lower net production of PGF in caruncular tissue. However, local effects were not observed with regard to the maximum production of PGF which was similar in both tissues, a point that was not apparent in the study of Louis et al. (1977) who did not separate intercaruncular tissue from myometrium. These findings imply that by Day 15 the presence of an embryo does not affect the maximum production of PGF synthesis in endometrial tissues.

The above results are consistent with the idea that the embryo stimulates the localized synthesis of a PG binding compound in caruncular tissue. This may account for the high tissue concentration of PGF in this tissue $(213 \mathrm{ng} / \mathrm{g}$, Table 4) which is released during incubation in the presence of indomethacin, leaving a low residual concentration in tissue. The amount of PGF produced during incubation for $90 \mathrm{~min}$ was $195 \mathrm{ng} / \mathrm{g}$ which combined with the residual concentration $(34 \mathrm{ng} / \mathrm{g}$, Table 4) gives a value $(257 \mathrm{ng} / \mathrm{g})$ closely similar to the initial concentration. The calculation also indicates that little PGF is formed from interconversions between endogenous primary prostaglandins such as PGE. The results are consistent with Ellinwood's (1978) view that a PG sequestering factor is present in endometrial slices incubated from 15-day pregnant sheep. How the embryo stimulates the synthesis of this compound is unclear; the effect may be direct or indirect, in the latter case arising from prolonged luteal 
progesterone secretion. Progesterone appears to be involved in stimulation of PGF retention in caruncular tissue because in other studies the tissue concentration of PGF in this tissue was also enhanced by progesterone treatment of ovariectomized ewes (Louis et al., 1977). Progesterone or oestradiol treatment of ovariectomized animals in the present study had complex and differential effects on the dynamics of PGF production in caruncular and intercaruncular tissues in that both steroids increased the maximum production in the latter while oestradiol depressed the net production in the former.

The physiological significance of a PGF binding component is not known but prostaglandins have been implicated in the process of implantation (see Kennedy, 1981). A different possibility is that synthesis of a PG-binding protein may facilitate a redirection of PGF secretion, with a lower release into the uterine vein (Thorburn et al., 1973; Barcikowski et al., 1974; Nett et al., 1976) and a higher secretion into the uterine lumen, as previously suggested by studies in sows (Bazer \& Thatcher, 1977) and ewes (Ellinwood et al., 1979), thereby protecting the corpus luteum from luteolysis in early pregnancy.

According to the studies of Ellinwood et al. (1979) the net production of PGF-2 $\alpha$ and PGE-2 (not measured in the present experiments) by endometrial slices in vitro was increased on Day 15 of pregnancy over values obtained in non-pregnant ewes. We did not observe an increase with minces of caruncular and intercaruncular tissues, the average value for the net production of PGF in the former being lower in pregnant than in non-pregnant animals. While this discrepancy may be attributable to differences in the recovery and preparation of tissue, an alternative possibility is that endometrial slices retain a tissue integrity which results in a higher net production of PGF. Huslig, Fogwell \& Smith (1979) have shown that stromal cells within the caruncles may have a special role in the increased cyclo-oxygenase activity observed during the late luteal phase of the oestrous cycle, so that separation of caruncular from intercaruncular tissue may deplete the provision of substrate to cells with high PG synthetic activity.

The ability of oestradiol or progesterone treatment of ovariectomized ewes to restore to normal values the other endometrial constituents examined largely confirms the results of previous workers. For example, oestradiol treatment restored both uterine weight, as found by Miller (1976) and Stone et al. (1978), and tissue protein concentration as reported by Murdoch $\&$ White (1968a, b). However, amongst the enzymes implicated in attachment and implantation, $\beta$-glucuronidase activity was higher in caruncular tissue in pregnant and non-pregnant animals, and this was mimicked in ovariectomized ewes by treatment with oestradiol. Treatment resulted in a significant interaction between steroids, particularly in intercaruncular tissue. Progesterone treatment greatly enhanced acid phosphatase activity in intercaruncular tissue. The technique would not identify subtle changes in activity between different cell types, and localized activation of acid hydrolases has been implicated in modifications of glycoproteins and glycolipids in the uterine lumen or on trophectoderm before implantation (Roberts et al., 1976; Denker, 1978).

The present study shows that significant differences exist in the response of the endometrial tissues to the presence of an embryo even before definitive implantation has commenced. Canonical variate analysis provides a means by which multiple endometrial constituents can be interrelated simultaneously, and it reveals that changes on Day 15 of pregnancy are most nearly mimicked in ovariectomized ewes by treatment with oestradiol and progesterone for the caruncular tissue but by oestradiol treatment for the intercaruncular endometrium. The analysis implies that the two tissues respond differently to ovarian steroid hormones at this stage of gestation, although the observation that oestradiol mimics most closely the biochemical responses seen in intercaruncular tissue on Day 15 of gestation requires a cautious interpretation since implantation in this species will occur after removal of known sources of maternal oestrogen secretion (ovaries and adrenals; Cumming, Baxter \& Lawson, 1974) provided exogenous progesterone is given. Furthermore, the absence of aromatase from sheep trophoblast in vitro suggests that the embryo is not the source of oestrogen. However, the possibility remains that the techniques used in the latter studies are not sensitive enough to detect a low level of 
activity which is effective locally; alternatively, oestrogens may be produced in early pregnancy by peripheral metabolism of neutral steroids in maternal tissues.

We thank Mr R. Proudfoot and his staff for expert help with experimental animals. J.K.F. acknowledges financial support of the Underwood Fund, Agricultural Research Council, London, and the Australian Wool Research Trust Fund, Australia and the Ford Foundation, U.S.A.

\section{References}

Anderson, S.G., Hackshaw, B.T., Still, J.G. \& Greiss, F.C. Jr (1977) Uterine blood flow and its distribution after chronic estrogen and progesterone administration. Am. J. Obstet. Gynec. 127, 138-142.

Baird, D.T. (1978) Local utero-ovarian relationships. In Control of Ovulation, pp. 217-233. Eds D. B. Crighton, N. B. Haynes, G. R. Foxcroft \& G. E. Lamming. Butterworths, London.

Barcikowski, B., Carlson, J.C., Wilson, L. \& McCracken, J.A. (1974) The effect of endogenous and exogenous estradiol-17 $\beta$ on the release of prostaglandin- $F_{2 \alpha}$ from the ovine uterus. Endocrinology 95, 1340-1349.

Bazer, F.W. \& Thatcher, W.W. (1977) Theory of maternal recognition of pregnancy in swine based on estrogen controlled endocrine versus exocrine secretion of prostaglandin $F_{2 u}$ by the uterine endometrium. Prostaglandins 14, 397-401.

Boshier, D.P. (1969) A histological and histochemical examination of implantation and early placentome formation in sheep. J. Reprod. Fert. 19, 51-62.

Challis, J.R.G., Heap, R.B. \& Illingworth, D.V. (1971) Concentrations of oestrogen and progesterone in the plasma of non-pregnant, pregnant and lactating guinea-pigs. J. Endocr. 51, 333-345.

Cumming, I.A., Baxter, R. \& Lawson, R.A.S. (1974) Steroid hormone requirements for the maintenance of early pregnancy in sheep: a study using ovariectomized adrenalectomized ewes. J. Reprod. Fert. 40, 443-446.

Davis, B.J. (1964) Disc electrophoresis. II. Method and application to human serum proteins. Ann. N.Y. Acad. Sci. 121, 404-427.

Denker, H.W. (1978) The role of trophoblastic factors in implantation. In Novel Aspects of Reproductive Physiology, pp. 181-212. Eds C. H. Spilman \& J. W. Wilks. Spectrum Publications, New York.

Dighe, K.K., Emslie, H.A., Henderson, L.K., Simon, L. \& Rutherford, F. (1975) The development of antisera to prostaglandins $\mathrm{B}_{2}$ and $\mathrm{F}_{2 \alpha}$ and their analysis using solid-phase and double antibody radioimmunoassay methods. Br. J. Pharmac. 55, 503-514.

Ellinwood, W.E. (1978) Maternal recognition of pregnancy in the ewe and the rabbit. Ph.D. thesis, Colorado State University.

Ellinwood, W.E., Nett, T.M. \& Niswender, G.D. (1979) Maintenance of the corpus luteum of early pregnancy in the ewe. II. Prostaglandin secretion by the endometrium in vitro and in vivo. Biol. Reprod. 21, 845-856.

Findlay, J.K. (1981) Embryo-maternal relationships in early pregnancy in the sheep. J. Reprod. Fert., Suppl. 30 (in press).
Fishman, W.H. (1974) $\beta$-Glucuronidase. In Methods of Enzymatic Analysis, 2nd edn. Vol. 2, pp. 929-943. Ed. H. U. Bergmeyer. Academic Press, New York.

Ford, S.P., Weber, L.J. \& Stormshak, F. (1977) Response of ovine uterine arteries to nerve stimulation after perfusions of prostaglandin $F_{2 \alpha}$, norepinephrine and neurotransmitter antagonists. Endocrinology 101, 659-665.

Gadsby, J.E., Heap, R.B. \& Burton, R.D. (1980) Oestrogen production by blastocyst and early embryonic tissue of various species. J. Reprod. Fert. 60, 409-417.

Gottesman, M.M. (1978) Transformation-dependent secretion of a low molecular weight protein by murine fibroblasts. Proc. natn. Acad. Sci. U.S.A. 75, 2767-2771.

Greiss, F.C., Jr \& Anderson, S.G. (1970) Uterine blood flow during early ovine pregnancy. Am. J. Obstet. Gynec. 106, 30-38.

Greiss, F.C., Jr \& Miller, J.B. (1971) Unilateral control of uterine blood flow in the ewe. Am. J. Obstet. Gynec. 111, 299-301.

Heap, R.B. \& Hamon, M. (1979) Oestrone sulphate in milk as an indicator of a viable conceptus in cows. Br. vet.J. 135, 355-363.

Heap, R.B., Gwyn, M., Laing, J.A. \& Walters, D.E. (1973) Pregnancy diagnosis in cows; changes in milk progesterone concentration during the oestrous cycle and pregnancy measured by a rapid radioimmunoassay. J. Agric. Sci., Camb. 81, 151-157.

Huslig, R.L., Fogwell, R.L. \& Smith, W.L. (1979) The prostaglandin forming cyclooxygenase of ovine uterus: relationship to luteal function. Biol. Reprod. 21, 589-600.

Kendall, K.G. \& Stuart, A. (1968) The Advanced Theory of Statistics, vol. 3, p. 285. Charles Griffin \& Co. Ltd, London.

Kennedy, T.G. (1981) Prostaglandins and the endometrial vascular permeability changes preceding blastocyst implantation and decidualization. Prog. reprod. Biol. 7, 234-244.

Kibbey, W.E., Bronn, D.G. \& Minton, J.P. (1977) Chromatographic patterns of prostaglandins using different lots of silicic acid. Prostaglandins 13, 1023-1032.

Legan, S.J., Karsch, F.J. \& Foster, P.L. (1977) The endocrine control of seasonal reproductive function in the ewe: a marked change in response to the negative feedback action of estradiol on luteinizing hormone. Endocrinology 101, 818-824.

Louis, T.M., Parry, D.M., Robinson, J.S., Thorburn, G.D. \& Challis, J.R.G. (1977) Effects of exogenous progesterone and oestradiol on prostaglandin $F$ and 
13,14-dihydro-15-oxo-prostaglandin $F_{2 u}$ concentrations in uteri and plasma of ovariectomized ewes. J. Endocr. 73, 427-439.

Lowry, O.H., Rosebrough, N.J., Farr, A.L. \& Randall, R.J. (1951) Protein determination with the Folinphenol reagent. J. biol. Chem. 193, 265-275.

Martal, J., Lacroix, M.-C., Loudes, C., Saunier, M. \& Wintenberger-Torrès, S. (1979) Trophoblastin, an antiluteolytic protein present in early pregnancy in sheep. J. Reprod. Fert. 56, 63-71.

Mayol, R.F. (1975) Studies on the synthesis of estrogenspecific uterine proteins. Comparison of methods of quantitative evaluation of double-isotope peaks. $\mathrm{Mol}$. cell. Endocr. 2, 133-146.

Menezo, Y. (1973) Etude electrophorétique des protéines des sécretions utérines de brebis au début de la gestation. C. r. hebd. Séanc. Acad. Sci. Paris, D 277, $337-340$.

Miller, B.G. (1976) RNA and protein metabolism in the oviduct and endometrium of the ewe at pro-oestrus: regulation by oestradiol and progesterone. J. Endocr. $69,57-66$.

Miller, B.G. \& Moore, N.W. (1976) Effect of progesterone metabolism in the genital tract and on survival of embryos in the ovariectomized ewe. Aust. J. biol. Sci. 29, 565-573.

Miller, B.G., Murphy, L. \& Stone, G.M. (1977) Hormone receptor levels and hormone, RNA and protein metabolism in the genital tract during the oestrous cycle of the ewe. J. Endocr. 73, 91-98.

Mitchell, M.D., Flint, A.P.F. \& Turnbull, A.C. (1976) Plasma concentrations of 13,14-dihydro-15-ketoprostaglandin F during pregnancy in sheep. Prostaglandins 11, 319-329.

Moor, R.M. (1968) Effect of embryo on corpus luteum function. J. Anim. Sci. 27, 97-116.

Murdoch, B.E. \& O'Shea, T. (1978) Activity of enzymes in the mucosal tissues and rinsings of the reproductive tract of the naturally cyclic ewe. Aust.J. biol. Sci. 31, 345-354.

Murdoch, R.N. (1970a) Glycogen, glycogenmetabolising enzymes, and acid and alkaline phosphatase in the endometrium of the ewe during early pregnancy. A ust. J. biol. Sci. 23, 1289-1296.

Murdoch, R.N. (1970b) Uterine endometrial phosphomonoesterase in relation to implantation in the ewe and rabbit doe. Aust. J. biol. Sci. 23, 1089-1097.

Murdoch, R.N. \& White, I.G. (1968a) Activity of enzymes in the endometrium, caruncles, and uterine rinsings of progestagen-treated and naturally cycling ewes. Aust. J. biol. Sci. 21, 123-131.

Murdoch, R.N. \& White, I.G. (1968b) The effect of oestradiol and progesterone on the activity of enzymes in the endometrium and caruncles of the ovariectomized ewe. J. Endocr. 42, 187-192.

Murphy, L., Stone, G.M., Miller, B.G. \& Moore, N.W. (1977) Oestradiol and progesterone: soluble receptor levels and metabolism in the uterus of the ovariectomized ewe. Aust. J. biol. Sci. 30, 225-228.
Nett, T.M., Staigmiller, R.B., Akbar, A.M., Diekman, N.A., Ellinwood, W.E. \& Niswender, G.D. (1976) Secretion of prostaglandin- $\mathrm{F}_{2 \alpha}$ in cycling and pregnant ewes. J. Anim. Sci. 42, 876-880.

O'Shea, T. \& Murdoch, B.E. (1978) $\alpha$-Glycosidase activity in the reproductive tract of the ewe. Aust. J. biol. Sci. 31, 363-371.

Peterson, A.J., Tervit, H.R., Fairclough, R.J., Havik, P.G. \& Smith, J.R. (1976) Jugular levels of 13,14dehydro-15-keto-prostaglandin $\mathrm{F}$ and progesterone around luteolysis and early pregnancy in the ewe. Prostaglandins, 12, 551-558.

Pope, W.F. \& Stormshak, F. (1979) Effect of the ovine conceptus on in vitro responses of uterine arteries to prostaglandin $\mathrm{E}_{2}$ and norepinephrine. Biol. Reprod. 20, 847-851.

Roberts, G.P., Parker, J.M. \& Symonds, H.W. (1976) Macromolecular components of genital tract fluids from the sheep. J. Reprod. Fert. 48, 99-107.

Rossier, G. \& Pierrepoint, C.G. (1974) The metabolism in vitro of $\mathrm{C}_{21^{-}}$and $\mathrm{C}_{19}$-steroids by pregnant sheep myometrium. J. Reprod. Fert. 36, 169-176.

Scaramuzzi, R.J., Baird, D.T., Boyle, H.P., Land, R.B. \& Wheeler, A.G. (1977) The secretion of prostaglandin F from the autotransplanted uterus of the ewe. $J$. Reprod. Fert. 49, 157-160.

Sheldrick, E.L., Wright, P.J., Allen, W.R. \& Heap, R.B. (1977) Metabolic clearance rate, production rate and source of progesterone in donkeys with fetuses of different genotypes. J. Reprod. Fert. 51, 473-476.

Staples, L.D., Lawson, R.A.S. \& Findlay, J.K. (1978) Maintenance of the corpus luteum in the ewe by intrauterine infusion of a soluble extract of ovine conceptus. Proc. 6th Asia and Oceania Congr. Endocr. Singapore, pp. 195-196.

Stone, G.M., Murphy, L. \& Miller, B.G. (1978) Hormone receptor levels and metabolic activity in the uterus of the ewe: Regulation by estradiol and progesterone. Aust. J. biol. Sci. 31, 395-403.

Thorburn, G.D., Cox, R.I., Currie, W.B., Restall, B.J. \& Schneider, W. (1973) Prostaglandin-F and progesterone concentrations in the utero-ovarian venous plasma of the ewe during the oestrous cycle and early pregnancy. J. Reprod. Fert., Suppl. 18, $151-158$.

Woessner, J.F. (1969) The physiology of the uterus and mammary gland. In Lysosomes in Biology and Pathology, pp. 299-329. Eds J. T. Dingle \& H. B. Fell. North Holland, Amsterdam.

Wyatt, C. (1978) Maternal-embryonic interactions during early pregnancy in the pig. Ph.D. thesis, University of Cambridge.

Zamiri, M.J. \& Blackshaw, A.W. (1979) Microfluorometric study of glycolytic enzymes in histologically defined areas of the sheep uterus and placentomes during pregnancy. Biol. Reprod. 21, 1257-1261.

Received 24 June 1980 